\title{
SELF CONCEPT, SELF ESTEEM AND SCHOOL SYSTEM: THE STUDY OF COMPARATION BETWEEN FULLDAY SCHOOL AND HALFDAY SCHOOL IN PURWOREJO
}

\author{
Itsna Iftayani \\ Universitas Muhammadiyah Purworejo \\ ifta_08@yahoo.co.id \\ Nurhidayati \\ Universitas Muhammadiyah Purworejo \\ nurhidayummurifda@gmail.com
}

\begin{abstract}
Self concept and self esteem are two psychological aspects that need to be attention in learning at school because a high of self concept and self esteem can influence students success in their learning. The objective of this research is to know about the differences about self concept and self esteem among elementary students with full day school and half day school system. The method used in this observation is comparison by comparing self concept and self esteem of elementary students with full day and half day system. The population of this research is 3 fullday Islamic elementary schools and 6 halfday Islamic elementary schools. The sample of this research is SD Islam Al-Madina as fullday school and SD Muhammadiyah Purworejo as halfday school. The data is gotten by the scale, observation, interviews and documentation. The result shows that there are no significant differences between self concept ( $\mathrm{t}=0,096$ with $\mathrm{df}: 47$ ) and self esteem $(\mathrm{t}=0,396$ with $\mathrm{df}: 47)$ among student who study in full day school and half day (regular) school system so it means that school system doesn't influence the quality of self concept and self esteem.
\end{abstract}

Keywords: self concept, self esteem, fullday school, halfday school

\section{INTRODUCTION}

In the global era, citizens are not only required to master the ability to read, write and count as a few decades ago but is required to have a number of other competencies like literacy digital era, thinking inventive-intellectual capital, the ability of interactive communicationssocial skills and personal and creating quality work and timely (Maftuh, 2010).

Demands to master a wide range of competencies also affected by education, because education is not only required to print a generation versed in scientific theories alone but also required to produce a generation that has a strong character that can compete globally with human resources featured on the Other countries. Based on global demand, the government has improved the existing curriculum into a new curriculum that is global perspective in the hope of scoring a generation that is superior.

Changes and improvements to the education system is not only done by the government, many schools both public and private that seeks to improve the quality of learning through the implementation of new curriculum, programs of creativity for students and the school system with study hours longer than other schools or often referred to as a full day school.

Full day school or often referred to as an integrated school is a school that combines time learning and playing children within 5 working days but by hours in school longer than regular school. This concept is actually against the 
background of the needs of parents who are mobile and have 5 working days in the office so I can have time off together with his son on Saturday and Sunday (Basuki, 2013). In due to high mobility, unified school also attention to several other factors, namely the lack of good society that feared the child would participate in the association and unfavorable environments and the tendency of children when at home just playing and not learning (Arsyadana, in Astuti, 2013). Based on the study, children full day school has a better reading achievement than children whose school half a day, but on the other achievements such as math and writing were not significant. On the social attitudes and daily behavior of school children who are half-day show minimal negative attitudes and general social attitudes better than the school system with a full day (Hildebrand, 2010).

Ideally integrated schools do have different activities with schools that have shorter hours of study. Implementation of full day school program is essentially not only adds time and effort to reproduce the subject matter but also to condition the child to have a good life habituation and psychological development, mental and moral. Therefore school with this system must be equipped with a recreational program in learning in order to avoid boredom in taking his studies.

Psychological aspects become important in learning, but it often does not get attention in school. Two of them are self-concept and self-esteem. The concept itself is one of the aspects that are important in the learning process, individuals who have a positive selfconcept usually have high confidence, able to accept criticism and not defensive, has a rational purpose and always willing to take risks and try new experiences. While selfesteem is necessary so that children can learn well. Maslow (Alwisol, 2004) suggests that there are some basic needs of the individual in order to learn well that physiological needs, safety needs, the need for affection, the need will be rewarded (self-esteem) and the need for selfactualization. Brooks et al (2010) suggested that the existing rules at school are very influential in building self-esteem. Andikurrahman (2012) revealed that children whose school system with a full day less in their social interactions, lack of confidence and also less sensitive to his friend.

Based on some of the findings of the researchers wanted to know how different self-concept and self-esteem of students between elementary school students with a full day school system and half-day school.

\section{Self-Concept}

As a psychological construct, selfconcept is defined differently by experts. Seifert and Hoffnung (1994), for example, defines the concept itself as "an understanding of the self or the idea of selfconcept." Santrock (1996) uses the term self-concept refers to the evaluation of specific fields of self-concept. Meanwhile, Atwater (1997) states that the concept of self is an overall sense of self, which includes one's perception of self, feelings, beliefs, and values that are associated with him. Furthermore, Atwater identified the concept of all three forms. First, body image, awareness of his body, that is how a person sees himself. Second, the ideal self, that is how the ideals and expectations of someone about himself. Third, the social self, that is how others see him.

Based on some of the above definition can be concluded that selfconcept is the idea of self-concept that includes beliefs, views, and assessment of a person against himself. The self-concept consists of how we look at the concept of self as a person, how we feel about the concept of self, and how a person's ability to think. After happened install, self- 
concept will go into the subconscious mind and will affect the person's level of consciousness at a time. The better or positive self-concept the easier it achieve success. Therefore, the concept of self-good / positive, someone will be optimistic, dare to try new things, dare to succeed and also dare to fail, confident, enthusiastic, feeling of self-worth, dare to set life goals, as well as act and think positively, Conversely, the bad or negative self-concept, it will be increasingly difficult for someone to succeed. Therefore, the concept of self-bad / negative will result in growing insecurity, fear of failure so do not dare to try things that are new and challenging, feel themselves silly, low self-esteem, feel themselves worthless, pessimistic, as well as a variety of feelings and behaviors other inferior.

\section{Self-Esteem}

Self-esteem is an evaluation of the individual against himself positively or negatively. This evaluation looks at how people judge themselves and rightly or wrongly ability and success gained. The assessment looks of their appreciation for the existence and significance of him. Individuals who have a positive self-esteem will accept and appreciate themselves what their (Santrock: 1999)

Self-esteem is the evaluation made by the individual. A person's attitude towards itself in a range of positive and negative dimensions. Esteem as the evaluation made by individuals on matters relating to him, expressing an attitude to agree or disagree and indicate the degree to which the individual has convinced himself that he is capable, important, successful and valuable. (James in Baron and Byrne, 2004).

Meanwhile, according to Branden Self-esteem is what people think and feel about themselves and not what she thought and felt by others about who he really is. Based on the above it can be concluded that self-esteem is the individual assessments of themselves either positively or negatively. So what is meant by selfesteem is the individual evaluations made regarding matters relating to him, which is expressed in a form you agree or disagree attitude and show that the individual believes himself as an individual capable, important, and valuable.

\section{Full Day School}

Full day school education system implies that apply learning or full day of teaching and learning by combining intensive teaching system ie, by adding hours of lessons for deepening the subject matter as well as personal development and creativity. Full Day School (FDS) applying a basic concept of "IntegratedActivity" and "Integrated-Curriculum". This is what distinguishes the school in general. In FDS all programs and activities of students in the school, both to learn, play, worship packaged in an education system. FDS is a pressure point on the achievement of students always learn in the process of quality learning that is expected there will be a positive change of each individual student as a result of the processes and activities in learning. The learning achievement in question lies in three areas, which are cognitive achievement.

As for the nature of cognitive achievement as students' ability to remember, understand, apply, observing, analyzing, making analysis and others. Concretely, the student can name and describe lessons last week, means the student can already be considered to have achievements that are cognitive, affective and achievements are achievements that are psychomotor.

\section{Halfday School}

According Nawawi (in Rahmawati, 2001) regular education is organized educational effort deliberate, planned, 
purposeful and systematic through an institution called school. Regular educational curriculum is the curriculum set by the Ministry of Education and has a relatively short learning time (regular). Regular school starts at $\mathbf{0 7 . 0 0}$ and ends at 10.00. Or half the regular school day school offers advantages, namely the lack of diverse learning methods to make children feel lighter in obtaining subjects, so that they do not feel bored or tired when home from school and be able to devote time to play at home or hanging out with family.

In addition to the above advantages, the regular school also has a weakness, that is by using effective time only for 3 hours, no other activities outside of the hours of study and play. This led to a lack of time for interaction with peers in school and not the establishment of open and effective communication with teachers (Herdiana, 2007).

Based on the description above theory, the hypothesis in this study was no difference in self-concept and self-esteem of students between elementary school students with a full day school system and half-day school.

\section{METHOD}

This research is a comparative study with the technique of random sampling (random). The population in this study were elementary school students of Islam in Purworejo. There are three Islamic elementary schools and six elementary schools full day halfday (regular), while samples in this study are SD Islam Al Madina Purworejo as schools that have a full day of school system and SD Muhammadiyah Purworejo as schools that have halfday school system. The study was conducted during the ten (10) months. Researchers collected data through observation, interviews, documentation and deployment scale concept and selfesteem. The scale used is the scale that has been adapted in the Indonesian language and easily understood by children. The analysis technique used is the independent sample t-test were calculated using SPSS.

\section{RESULT AND DISCUSSION}

\section{Homogeneity test}

Based on data obtained through the deployment of self-concept scale and have been analyzed using SPSS software 15 . Samples of student data is studied with the same system or a full day and halfday homogeneous ( $f=2,893, p=0,096 . p>0$, 05 ). This can be seen in Table 1 below:

Table 1. Test Homogeneity Self Concept

\begin{tabular}{llcc}
\hline & \multicolumn{2}{c}{$\begin{array}{c}\text { Levene's Test for Equality of } \\
\text { Variances }\end{array}$} \\
\cline { 3 - 4 } & \multicolumn{1}{c}{ S } & Sig. \\
\cline { 3 - 4 } KD & $\begin{array}{l}\text { Equal variances } \\
\text { assumed }\end{array}$ & 2.893 & Upper \\
\cline { 2 - 3 } & $\begin{array}{l}\text { Equal variances not } \\
\text { assumed }\end{array}$ & & .096 \\
\hline
\end{tabular}

Sample data is self-esteem in students learning the same system or a full day and halfday homogeneous $(f=1.214, p$ $=0,27, \mathrm{p}>0,05)$.

Table 2. Homogeneity Test of Self-Esteem

\begin{tabular}{llcc}
\hline & & \multicolumn{2}{c}{$\begin{array}{c}\text { Levene's Test for Equality of } \\
\text { Variances }\end{array}$} \\
\cline { 3 - 4 } & & $\mathrm{F}$ & Sig. \\
\cline { 3 - 4 } & Lower & Upper \\
\hline HD & $\begin{array}{l}\text { Equal variances } \\
\text { assumed }\end{array}$ & 1.214 & .276 \\
\cline { 2 - 4 } & $\begin{array}{l}\text { Equal variances not } \\
\text { assumed }\end{array}$ & & \\
\hline
\end{tabular}

\section{Hypothesis testing}

Based on the calculation results in Table 3, there was no significant difference in the self concept of primary school students to learn the system and a full day school half-day school. It can be seen that $t$ $=0,096$ degrees of freedom 0,47 .

Based on the calculations in Table 4 of hypothesis testing students' self-esteem in school full day and halfday school can be 
seen that $t=-0,396$ degrees of freedom 47 . This shows that there are no significant differences in self-esteem of primary school students to learn with full system half day school and day school.

Table 5. Results Descriptive Analysis Self Concept Fullday School (SD Muhammadiyah Purworejo) and Halfday School (SD Islam Al Madina Purworejo)

\begin{tabular}{lccc}
\hline Sistem Sekolah & Mean & SD & N \\
\hline Fullday School & 13,187 & 1,37 & 16 \\
Halfday School & 13,515 & 0,95 & 33
\end{tabular}

According to the table of descriptive analysis above, it can be seen that the difference in the mean difference (mean) self concept only $\mathrm{O}, 0328$. Average selfconcept students learn by fullday system is $13 \quad 187$ and the average self-concept students learn by halfday system is 13,515 , thus it can be seen that the self-concept of students studying at higher halfday system of self-concept students learn by fullday system.

Table 6. Results Descriptive Analysis of Self-Esteem Fullday School (SD Muhammadiyah Purworejo) and Halfday School (SD Islam Al Madina Purworejo)

\begin{tabular}{llll}
\hline Sistem Sekolah & Mean & SD & N \\
\hline Fullday School & 9,000 & 0,82 & 16 \\
Halfday School & 9,121 & 1,08 & 33 \\
\hline
\end{tabular}

According to the table of descriptive analysis above, it can be seen that the difference in the mean difference (mean) self concept only $\mathrm{O}, \mathbf{1 2 1}$. Average selfesteem of students studying with the system is a full day 9, ooo and the average self-concept students learn by halfday system is 9,121 , thus it can be seen that the self-esteem of students studying at higher halfday system of self-concept students learn by fullday system.

The results showed that no significant differences in self-concept of students studying at the school with a full day and halfday system. Nonetheless, however self-concept students learn by fullday systems have lower self-concept than students who studied with halfday system. The absence of significant differences in self-concept of students could be possible Since the child's self concept is also influenced various other factors such as upbringing, environment, age, and so on.

Tabel 3. Uji Hipotesis Konsep Diri pada Siswa Fullday School dan Halfday School

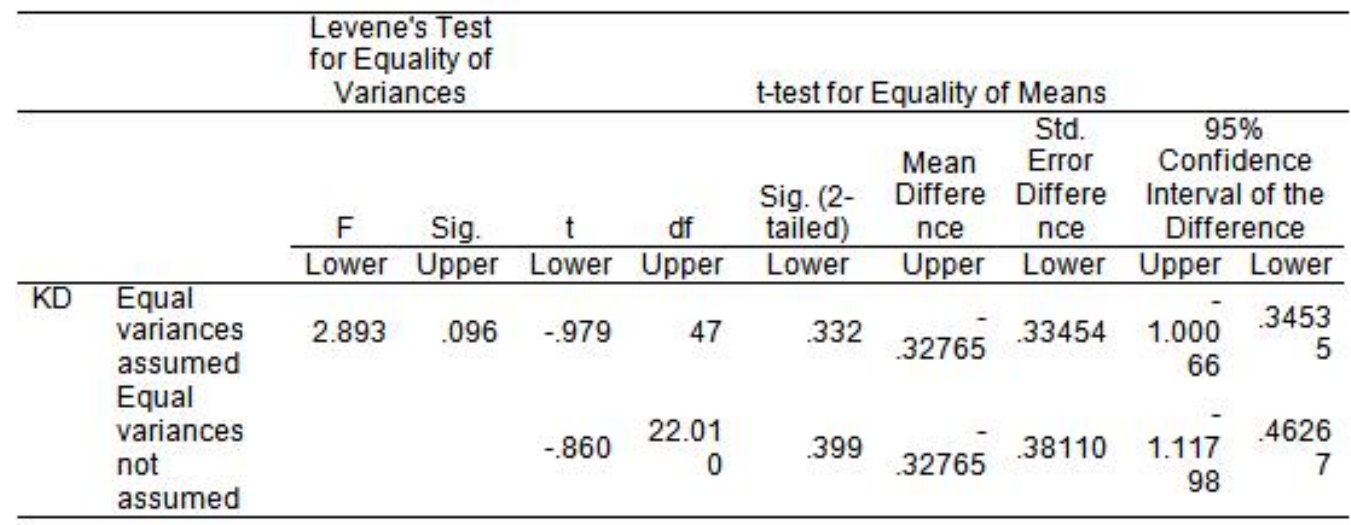


Tabel 4. Uji Hipotesis Harga Diri pada Siswa Fullday School dan Halfday School

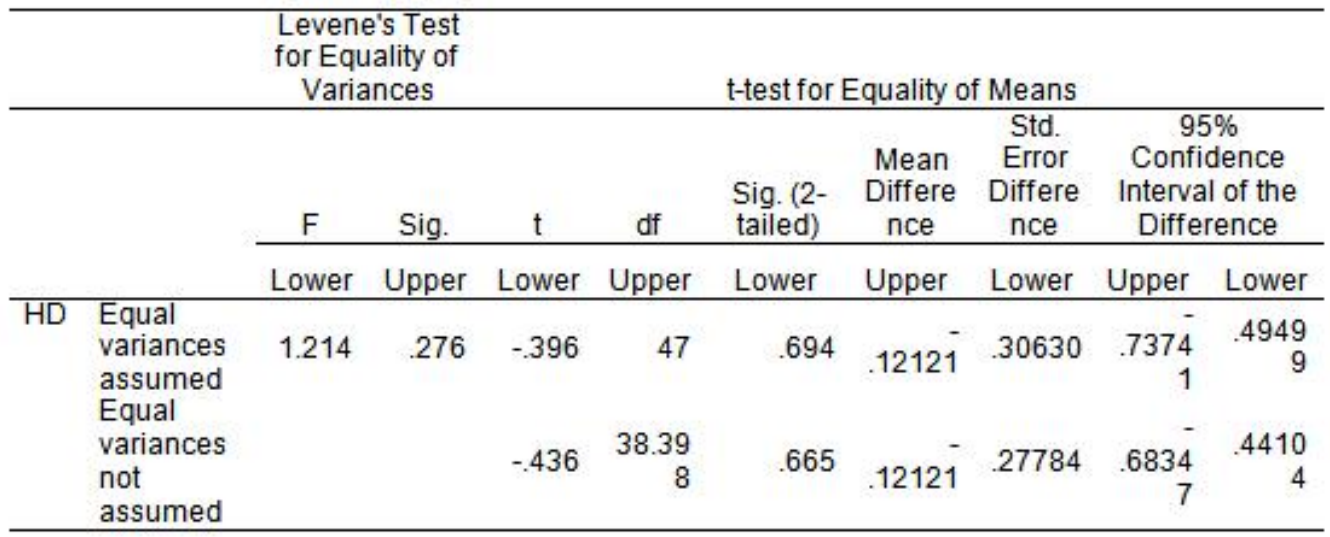

The self-concept of students at the two schools is also a high average. Similarly, self-esteem, self-concept of students at two high schools as a learning system that is relaxed and not stuffy, teachers can motivate students and attitudes of teachers towards students. Astuti (2014) states that the role of social factors influence students' self-concept, social role of this form of positive encouragement of teachers to students in the form of praise when students actively in the learning process in the classroom.

The self-concept and self-esteem is a psychological aspect is very important and must be considered in the learning process. When students have a good selfconcept and students will be individuals who are positive, dare to try and take the risk, optimism, confidence and enthusiasm set the direction and purpose in life.

Self-esteem is also one aspect that must be considered. Esteem of students at two schools (full day and halfday school) did not differ significantly. In general, selfconcept in these two high schools. This can be influenced by the school system are not rigid and authoritarian, the teachers were good and harmonious school environment. Scott (1996) revealed that self-esteem is influenced by teachers and school employees who care and want to help the students, the curriculum ideal, conducive learning environment and also a good relationship between the school and families. This suggests that the role of the teacher and manager of a go to school also greatly affect their self-esteem.

Maslow (2004) put the self-esteem as the individual needs that must be owned by individuals so that development can be optimal. This needs to occupy the position of the individual in question 4. The needs are basic needs (eating, drinking and sleeping), the need for security, the need to be loved, the need to be appreciated and the need for self-actualization. For Maslow, when these needs are not met then the learning process will not take place properly and student academic success can not be achieved. Meanwhile Shore argued that self-esteem will influence decisionmaking, interaction with others, academic achievement, the ability to focus and ability to take decisions.

The self-concept and self-esteem of students in school full day and halfday were not significantly different. This indicates that the length of the students in the school did not show a great influence. Students who study with regular study hours (4-5jam) with students who learn by studying long hours (6-7jam) had the same concept and self-esteem high. Based on interviews and observations of climate in these two schools have in common is the relationship of teachers and students that close and harmonious, joyful learning and school environment conducive. Beane (1982) revealed that the curriculum in 
schools is one factor that can improve selfconcept of students, the curriculum is meant here is the hidden curriculum that includes how the expectations of teachers to students and learning climate in the classroom.

\section{CONCLUSION}

The results showed that there was no significant difference in self-concept and self-esteem among the students who studied with fullday system and student learning by halfday system (regular) so that it can be said that the school system does not affect the level of self-concept and selfesteem. The self-concept and self-esteem is formed as a fun learning process, teachers who are authoritarian and a conducive learning atmosphere.

\section{REFERENCES}

Alsa, Asmadi. (2007). Pendekatan Kuantitatif dan Kualitatif Serta Komunikasinya dalam Penelitian Psikologi. Yogyakarta: Pustaka Pelajar

Alwisol. (2004). Psikologi Kepribadian. Malang: UMM Press.

Arifin, Zainal. (2012). Pengembangan Managemen Mutu Kurikulum Pendidikan Islam. Yogyakarta: DIVA Press.

Astuti, Marfiah. (2013). Implementasi Program Fullday School Sebagai Usaha Mendorong Perkembangan Sosial Peserta Didik TK Unggulan Al-Ya'lu Kota Malang. Jurnal Kebijakan dan Pengembangan Pendidikan Vol. 1 No. 2, 2 Juli 2013: 133-140. ISSN: 2337-7623; EISSN: $2337-7615$.

Basuki, Sukur. (2014). Fullday school, harus proporsional sesuai jenjang dan jenis sekolah.

Smkn1lmj.sch.id/dl/fuldyaschool.p df. diunduh pada tanggal 22 Maret 2014.
Brooks, Rachele \& Noy, Michele Van. (2010). Study of Self-Esteem and Se lf-Efficacy as Psychosocial Educatio nal Outcomes:The Role of High Sch ool Experiences and Influences. The Spencer Foundation, National Science Foundation, National Institute of Child Health and Human Development, and the Office of Population Research at Princeton University.

Diekhoff, George. Statistics For Social and Behavioral Science. USA: Brown Publisher.

Hewitt, Paul M \& Denny, George S. (2010). The four-day school week: impact on academic performance. University of Arkansas: Paper presented at the National Council of Professorof Educational Administratio. Annual Summer Conference, Washington DC, August 4, 2010.

Hildebrand, Charlene. (2010). Effect of allday, and half-day kindergarten programming on reading, writing, math and classroom social behaviors. National FORUM Journal University of NebraskaKearney.

Ismail, Zaenat. (2011). Student self esteem and their perception of theacher behavior: a study off class grouping system in Pakistan. International Journal of Bussiness and Social Science, Vol. 2, No. 16, September 2011.

Hadi, Sutrisno. (2004). Metodologi Research 4. Yogyakarta: Andi

Hadi, Sutrisno. (2004). Statistik Jilid 2. Yogyakarta: Andi.

Hanoever, Teem. (2010). Full-day kindergarten and academic achievement. Honoever Research: District Administration Practice, September 2010. P. 202.756.2971.

Maftuh, Benyamin. (2010). Memperkuat peran IPS dalam Membelajarkan 
Ketrampilan Sosial dan Resolusi Konflik. Pidato pengukuhan jabatan guru besar dalam bidang pendidikan ilmu pengetahuan sosial pada Fakultas Pendidikan Ilmu Pengetahuan Sosial Universitas Pendidikan Indonesia.

Syah, Muhibbin. (2004). Psikologi Pendidikan dengan Pendekatan Terpadu. Bandung: Remaja Rosdakarya.

Zimmer-Gembeck, M. J \& Collins, W. A . (2003). Authonomy development during adolescence. In G. R Adams \& M Berzonsky (Eds), Blackwell Handbook of adolescence (pp. 175204). Oxford: Blackwell Publisher. 